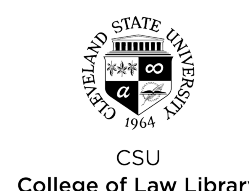

Cleveland State University

College of Law Library

\title{
EngagedScholarship@CSU
}

1994

\section{Courts Take Close Look at Adult Use Regs}

\author{
Alan C. Weinstein \\ Cleveland State University, a.weinstein@csuohio.edu
}

Follow this and additional works at: https://engagedscholarship.csuohio.edu/fac_articles

Part of the First Amendment Commons, Land Use Law Commons, and the Urban Studies Commons How does access to this work benefit you? Let us know!

\section{Repository Citation}

Weinstein, Alan C., "Courts Take Close Look at Adult Use Regs" (1994). Law Faculty Articles and Essays. 564.

https://engagedscholarship.csuohio.edu/fac_articles/564

This Article is brought to you for free and open access by the Faculty Scholarship at EngagedScholarship@CSU. It has been accepted for inclusion in Law Faculty Articles and Essays by an authorized administrator of EngagedScholarship@CSU. For more information, please contact research.services@law.csuohio.edu. 


\section{Courts Take Close Look at Adult Use Regs}

\author{
By Alan C. Weinstein
}

Regulations imposed on "adult businesses"1 by state or local government raise serious constitutional issues because the First Amendment's guarantee of freedom of expression extends to sexually oriented media. ${ }^{2}$ The importance of these issues can be seen in the fact that between 1976 and 1991, the U.S. Supreme Court addressed five cases challenging the constitutionality of state or local regulation of adult businesses. See Table 1 . In addition, state and lower federal courts have ruled on hundreds of adult business cases. This article provides an update on recent adult business cases dealing with locational restrictions, public indecency laws, licensing requirements, and public health regulations.

There are several reasons why adult business regulations are challenged so frequently. First, adult business owners have a great deal at stake financially. For example, the August 8, 1988 issue of Newsweek (p. 3) reported that adult entertainment grossed an estimated $\$ 8$ billion at that time. Furthermore, adult business owners have a good chance of winning their court cases. Regulations that impinge on an adult business's freedom of expression lose the presumption of constitutionality that normally applies to municipal ordinances, and the burden of proof shifts to local government to justify its restrictions. Also, cases testing the federal constitutionality of regulations can be brought in federal courts before judges with life tenure who most likely have significant experience with First Amendment issues.

\footnotetext{
Alan Weinstein is a professor of law and planning at Cleveland State University's Cleveland-Marshall College of Law and Levin College of Urban Affairs and is a reporter for Land Use Law \& Zoning Digest.

1. The terms "adult business" or "adult entertainment business" typically refer to bookstores, theaters, mini-theaters, video rental stores, bars, and cabarets that purvey "adult entertainment" consisting of performances or merchandise characterized by an emphasis on nudity and sexual acts. See generally, J. Gerard, Local Regulation of ADULT Businesses (1992), and F. Strom, Zoning Control of Sex Businesses (1977). In this article, the terms "adult businesses" and "adult uses" are used interchangeably.
}

2. Obscene material is not protected by the First Amendment. See Miller v. California, 413 U.S. 15 (1973). Non-obscene pornography, however, is entitled to protection under the First Amendment. See Young v. American Mini-Theatres, 427 U.S. 50 (1976), 28 ZD 329, and Barnes v. Glen Theatres, Inc., 111 S.Ct. 2456 (1991).
In state courts, however, judges often are elected and may be less familiar with the sophisticated issues of First Amendment law.

Second, local elected officials may be regulating adult businesses stringently because of political pressure rather than planning or legal needs. Public officials normally argue that these regulations are justified because of the need to protect adjacent areas from the adult uses' harmful secondary effects or to prevent related crimes, including drug sales, sexual assaults, prostitution, and illegal homosexual activity. While adult businesses undeniably raise such concerns, imposing stringent restrictions on these businesses is also very attractive politically to elected officials. A significant percentage of voters-probably an overwhelming majority-disapprove of adult uses and favor regulating them heavily, or even banning them. Despite their numerous customers, ${ }^{3}$ adult uses understandably have few vocal supporters.

Adult use regulations must be drafted with skill and precision and will often need to be supported by extensive

\begin{tabular}{|c|c|}
\hline Case & Description \\
\hline $\begin{array}{l}\text { Young v. American Mini-Theaters, } \\
427 \text { U.S. } 50 \text { (1976), } 28 \text { ZD } 329\end{array}$ & $\begin{array}{l}\text { Upholding a Detroit ordinance requiring } \\
\text { the dispersion of adult businesses. }\end{array}$ \\
\hline $\begin{array}{l}\text { Schad v. Borough of Mount Ephraim, } \\
452 \text { U.S. } 61 \text { (1981), 33 ZD } 254\end{array}$ & $\begin{array}{l}\text { Striking down a New Jersey municipality's } \\
\text { ban on all live entertainment. }\end{array}$ \\
\hline $\begin{array}{l}\text { City of Renton v. Playtime Theaters, Inc., } \\
475 \text { U.S. } 41 \text { (1986), 38 ZD } 310\end{array}$ & $\begin{array}{l}\text { Upholding a Seattle suburb's ordinance } \\
\text { concentrating adult businesses in five } \\
\text { percent of city. }\end{array}$ \\
\hline $\begin{array}{l}\text { FW/PBS, Inc. v. City of Dallas, } \\
493 \text { U.S. } 215(1990), 42 \text { ZD } 75\end{array}$ & $\begin{array}{l}\text { Striking down licensing provisions of a } \\
\text { comprehensive adult business zoning } \\
\text { and licensing ordinance. }\end{array}$ \\
\hline $\begin{array}{l}\text { Barnes v. Glen Theatres, Inc., } \\
111 \text { S.Ct. } 2456 \text { (1991) }\end{array}$ & $\begin{array}{l}\text { Upholding Indiana public indecency statute } \\
\text { that barred nude dancing performances. }\end{array}$ \\
\hline
\end{tabular}

planning studies because courts closely examine these ordinances for First Amendment violations. Unfortunately, in an era of diminished public funding, the resources for such efforts may simply be unavailable. This fact, combined with strong political pressure for fast but strict solutions, too often produces ill-conceived and poorly drafted ordinances that will be successfully challenged.

\section{SUPREME COURT ADULT USE CASES}

The first three Supreme Court rulings on adult business regulation listed in Table 1-Young, Schad, and City of Renton-involved challenges to municipal land-use ordinances. The fourth case, FW/PBS, Inc., dealt with a challenge to the licensing provisions of a comprehensive adult business ordinance. In the fifth and most recent case,

3. The enormous extent of nationwide patronage for adult businesses- $\$ 8$ billion in 1988 - has already been shown. What that means at the local level can be illustrated by a 1994 federal district court decision which revealed that a single "members only" club in suburban Maryland that featured topless dancing had a membership list of 6,000 . Zanganeh v. Hymes, - F. Supp. - 1994 WL 29980 (D. Md.). 
Barnes, a sharply divided Court upheld an Indiana public indecency statute prohibiting public nudity that had been enforced to bar nude dancing performances at two adult businesses in South Bend.

These cases confirm that municipalities may single out adult uses for special regulatory treatment if the municipality can show a substantial public interest in regulating such uses unrelated to the suppression of speech and if the regulations allow for a reasonable number of alternative locations. However, the ordinance will be struck down when cities attempt to regulate because they object to the sexually explicit messages conveyed by adult business. Courts will also void regulations that seek to exclude all adult uses through an outright ban, excessive locational requirements, or undue discretion placed in the hands of officials who review applications for special use permits or business licenses.

\section{LOCATIONAL RESTRICTIONS}

The Supreme Court has approved ordinances that disperse (Young) or concentrate (Renton) adult businesses if a municipality can demonstrate that the ordinance is based on a substantial governmental interest unrelated to the suppression of speech and sufficient alternative locations remain available. In Young, the Court approved a Detroit dispersion-type ordinance that was aimed at deterring the negative secondary effects of adult businesses, such as neighborhood deterioration or crime. While the Young decision emphasized Detroit's well-documented studies of local conditions, in Renton, the Court ruled that municipalities did not have to undertake their own studies, but could rely on the findings of other cities if the local officials reasonably believed the findings were relevant to their own problems with adult uses.

\section{Reasonable Belief of "Secondary Effects"}

In recent cases, this "reasonable belief" standard has been at issue where it was alleged that: (1) local officials had not paid enough attention to the findings of other cities to satisfy the standard, or (2) the nature of the adult uses being regulated were so different from the uses in the city where the studies were done that the standard was not met. An example of the first claim is seen in the case of Lakeland Lounge of Jackson, Inc. v. City of Jackson, Mississippi, 800 F. Supp. 455 (S.D. Miss.), rev'd and remanded, 973 F.2d 1255 (5th Cir. 1992).

Attention to Findings. In Lakeland, a federal district court voided the ordinance because it found no indication that the members of the city council had ever looked at the studies of secondary effects experienced in other cities or received any staff summaries of these studies. Acknowledging it was a close question, the district court concluded that a summary of the secondary effects should have been presented to the council. In addition, the court said that the council should have been able to produce evidence of its reliance on some formal study leading to its conclusion that if the adult uses were not regulated, the secondary effects would occur. This decision was reversed on appeal-the Fifth Circuit Court of Appeals ruled that the members of the city council could reasonably rely on the findings of the city's planning office and city attorney, who undeniably considered the studies of secondary effects. The municipality's loss in the lower court, however, could easily have been avoided if the staff had given the members of the city council a written report or summary of the studies relied upon by those who prepared the proposed ordinances and also orally presented the findings contained in the report or summary to the council.

The correct approach to follow can be seen in Holmberg $v$. City of Ramsey, 12 F.3d 140 (8th Cir. 1993), which upheld the city council's conclusion regarding secondary effects. In Holmberg, the city based this decision on reports of the city planner, recommendations by the city planning commission, and local public hearings. In Thames Enterprises, Inc. $v$. City of St. Louis, 851 F.2d 199 (8th Cir. 1988), 41 ZD 21, the court upheld an ordinance in which the findings of secondary effects were based on a legislator's personal observations and judgments together with the results of research from other sources. However, in SDJ, Inc. v. City of Houston, 837 F.2d 1268 (5th Cir. 1988), 40 ZD 312, the court stated that mere conclusory statements as to the deleterious effects of adult businesses will not pass the standard.

Nature of Business. The second issue, involving the nature of the adult business, has arisen in cases where locational requirements were applied to video stores whose patrons rent or purchase materials to view at home. In ILQ Investments, Inc. v. City of Rochester, 816 F. Supp. 516 (D.Minn.

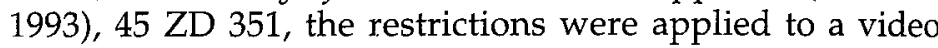
store that offered both sexually explicit and non-sexually explicit materials. However, in World Wide Video v. City of Tukwila, 816 P.2d 18 (Wash. 1991), cert. denied sub nom. City of Tukwila v. World Wide Video, 112 S.Ct. 1672 (1992), 44 ZD 96, the affected video store dealt only in sexually explicit material. In each case, the court ruled that none of the studies of secondary effects relied upon by elected officials provided evidence that take-out video stores cause the same type of adverse effects as adult businesses in which material or performances are viewed on premises.

In $I L Q$, the court further noted that there was no evidence that the secondary effects created by businesses that offer only sexually explicit material would result from a business that offered both adult and standard videos. ${ }^{4}$ These cases strongly suggest that regulation of take-out video stores that offer adult entertainment cannot be based solely on findings of secondary effects caused by adult businesses where patrons view materials or performances on the premises, but must be justified by a finding of specific negative secondary effects associated with such take-out businesses.

4. California's highest court has made some interesting comments about assessing the validity of the regulation of businesses that offer both adult and standard material. In People v. Superior Court, 774 P.2d 769 (1989), 41 ZD 346, the city of Long Beach charged the operators of a two-screen theater with unlawfully establishing an adult entertainment business, in violation of the locational restrictions of a dispersionstyle ordinance, each time they exhibited an X-rated movie on one of the screens. The California Supreme Court was unanimous in finding this "single use" standard invalid-citing Tollis, Inc. v. San Bernardino County, 827 F.2d 1329 (9th Cir. 1987), 41 ZD 43, which held that defining a theater as an "adult use" based on a single showing of an adult movie was unconstitutional absent evidence that a single showing would have any harmful secondary effects on the community.

But the court was split 4-3 when it tried to define an appropriate constitutional standard for an adult use. The majority (four justices) rejected an earlier "preponderance" standard announced in Pringle v. City of Covina, 171 Cal. Rptr. 251 (Cal. App. 1981), 33 ZD 121, in favor of a new test, "the regular and substantial course of conduct" standard. This new test would allow cities "greater flexibility" in regulating adult uses while not allowing zoning to be used as a "'pretext for suppressing expression."' Id. at 777, quoting Young at 427 U.S. 84. 


\section{Commentary}

\section{The Relevant Realty Market}

The standard emerging from recent cases focuses on whether there are an adequate number of potential sites for adult businesses within the relevant local real estate market. In Renton, the Supreme Court stated that while government may not "effectively deny" adult businesses "a reasonable opportunity to open and operate," adult businesses "must fend for themselves in the real estate market on an equal footing with other prospective purchasers and lessees ..." Since the Renton decision, courts have struggled to develop a standard for judging the reasonableness of locational restrictions. This standard is crucial because municipalities in regulating adult uses can (consciously or otherwise) severely restrict the number of potential sites available to adult uses and/or require them to operate in undesirable locations. In fact, the adult use regulations may reduce the number of available sites to the extent that adult uses are banned in a community. This exclusion of adult uses is particularly likely when combined with amortization provisions forcing fast termination or relocation of adult uses. ${ }^{6}$

This "real estate market" standard appeared initially in Woodall v. City of El Paso, 959 F.2d 1305 (5th Cir. 1992), 44 ZD 359. There, after recognizing that Renton "contemplated that there was a 'market' in which [adult] businesses could purchase or lease real property on which business could be conducted," the court ruled that "land with physical characteristics that render it unavailable for any kind of development, or legal characteristics that exclude adult businesses, may not be considered 'available' for constitutional purposes under Renton." The court, however, declined to address "the relationship between the economics of site location and the constitutionality of an adult business zoning ordinance." Id. at 1306.

Subsequently, in Topanga Press, Inc. v. City of Los Angeles, 989 F.2d 1524 (9th Cir. 1993), 45 ZD 273, the Ninth Circuit squarely faced the economics question avoided in Woodall. The court recognized that the distinction between economic and other factors is difficult to maintain because physical and legal unavailability can be presented as economic unavailability. For example, a site located five miles from the nearest public road could be seen either as physically unavailable or, given the cost of constructing an access route, as economically unavailable. The Ninth Circuit argued that the economics of site location is a valid inquiry, so long as the economic analysis focuses on whether a site is part of the relevant real estate market. The Ninth Circuit said:

Accordingly, we do not think that Renton forbids a court to consider economics when evaluating whether a particular site is in fact part of the real estate market. For purposes of Renton, the distinction is between consideration of economic impact within an actual business real estate market

5. 475 U.S. at 54. In Renton, the Supreme Court rejected the Ninth Circuit's finding that there were no "commercially viable" sites for adult businesses in a largely developed 520-acre area, amounting to five percent of all land in the city, to which adult businesses were restricted.

6. See, e.g., Woodall v. City of El Paso, 959 F.2d 1305 modifying 950 F.2d 255 (5th Cir.), cert. denied, 113 S.Ct. 304 (1992) (requiring all 39 adult businesses in city to relocate); Alexander v. City of Minneapolis, 928 F.2d 278 (8th Cir. 1991) (requiring at least 30 of 36 adult businesses to relocate to 0.54 percent of the total land area of the city). and consideration of cost to determine whether a specific relocation site is part of the relevant market. A court may not consider the former, but it may consider the latter when determining whether a specific site is reasonably suitable for the operation of a business. 989 F.2d 1530.

After reviewing several decisions involving locational restrictions, the Ninth Circuit in Topanga Press noted the prerequisites for a particular site to be deemed part of the relevant real estate market. In Renton, the Court stressed that properties need only be "potentially" available to be part of the relevant real estate market. However, the Ninth Circuit in Topanga Press argued that, first, "a property is not 'potentially' available when it is unreasonable to believe that it would ever become available to any commercial enterprise." Second, sites in manufacturing or industrial zones are part of the market if they are: reasonably accessible to the general public; have a proper infrastructure of sidewalks, roads, and lighting; and are generally suitable for some form of commercial enterprise. Third, and most obviously, commercially zoned locations are part of the real estate market. Once a site qualifies as part of the real estate market under these criteria, however, its "commercial viability" as an adult business location is irrelevant.

The court applied these criteria to the challenged Los Angeles ordinance. Much of the land "potentially available" for the relocation of adult businesses, the Ninth Circuit ruled, was not part of the real estate market. Accordingly, this appeals court struck down the ordinance because it did not provide sufficient "reasonably available" sites for the relocation of adult businesses. Among the areas that the court identified as outside the relevant real estate market were thousands of acres submerged beneath the ocean or harbor, landing strips at Los Angeles Airport, a 200-acre landfill, 600 acres used for the Van Nuys airport, 4,357 acres used by the Port of Los Angeles and/or oil refineries, land occupied by a defense plant, a GM plant, junkyards, steelyards, car storage lots, hospitals, and other large institutions. Id. at 1532 .

The Topanga Press approach presents a workable standard for judging whether sites for adult businesses are "reasonably available." While this approach allows consideration of economic factors to define the relevant real estate market, it bars consideration of "commercial viability" for particular sites that are found to be within the relevant market. In effect, it permits municipalities to impose significant locational restrictions on adult businesses to avoid undesirable secondary effects, but it prevents local government from effectively banning such businesses by exiling them to locations that present insuperable physical, legal, or economic barriers to operation or development.

The starting point for drafting locational restrictions to meet the Topanga Press test is, of course, the three factors already noted. In addition, planners need to be cautious about how much spacing requirements reduce the number of sites available for adult uses. For example, an ordinance provision that no adult use may locate within 1,000 feet of another adult use or within 1,000 feet of a church, school, or playground can dramatically reduce the available sites. To better understand the effect of a 1,000 foot distancing requirement, consider that the requirement erects an imaginary circular fence enclosing 72 acres that are barred to adult 
uses. (The 1,000 foot requirement creates a circle with a radius of 1,000 feet and thus an area of 3,141,600 square feet, which equals 72 acres.) As new adult uses are established, new 72-acre circles banning adult uses are created.

\section{NUDE DANCING AND PUBLIC INDECENCY LAWS}

As noted earlier, in Barnes v. Glen Theatres, 111 S.Ct. 2456 (1991), two adult businesses claimed a violation of their First Amendment rights when Indiana's public indecency statute was applied to ban totally nude dancing as a form of entertainment. ${ }^{7}$ After a lengthy journey through the federal courts, a majority of the Seventh Circuit concluded that non-obscene nude dancing performed for entertainment is expression protected by the First Amendment. The public indecency statute applied to this dancing, the court ruled, was an improper infringement of that expressive activity because its purpose was to prevent the message of eroticism and sexuality conveyed by the dancers. See Miller $v$. Civil City of South Bend, 904 F.2d 1081 (7th Cir. 1990). The Supreme Court reversed this judgment, but failed to reach a single rationale for its decision. Chief Justice Rehnquist, joined by Justices $\mathrm{O}^{\prime}$ Connor and Kennedy, delivered the opinion of the Court upholding the statute, with Justices Scalia and Souter writing separate concurring opinions. Justice White, joined by Justices Marshall, Blackmun, and Stevens, dissented.

Chief Justice Rehnquist's plurality opinion acknowledged that nude dancing is expressive conduct protected by the First Amendment, but found that it was only "marginally" within the amendment's "outer perimeters." Rehnquist argued that the statute was not aimed at the erotic message conveyed by the dancing but sought to ban all public nudity, whether or not it is combined with expressive activity. Thus, according to Rehnquist, the statute should be seen as a form of "time, place or manner" restriction which could be judged under the standards set forth in United States v. O'Brien, 391 U.S. $367(1968){ }^{8}$

Rehnquist found that Indiana's public indecency statute used the state's police power to further a substantial government interest in protecting order and morality by banning public nudity. Restricting nudity on moral grounds, Rehnquist argued, is unrelated to the suppression of free expression. (In making this point, Rehnquist relied on language in $O^{\prime} B r i e n$ rejecting an "expansive" notion of expression as any conduct

7. The Indiana statute declares that anyone who knowingly or intentionally appears in a state of nudity in a public place commits "public indecency," a Class A misdemeanor. Nudity is defined as "the showing of the human male or female genitals, pubic area, or buttocks with less than a fully opaque covering, the showing of the female breast with less than a fully opaque covering of any part of the nipple, or the showing of the covered male genitals in a discernibly turgid state." Ind. Code § 3545-4-1 (1988).

8. O'Brien held that when "speech" and "nonspeech" elements are combined in the same course of conduct, a sufficiently important governmental interest in regulating the nonspeech element can justify incidental limitations on First Amendment freedoms. In O'Brien, the Court stated a four-part test for evaluating government regulations that incidentally affect expressive activity. The government regulation is sufficiently justified if: (1) it is within the constitutional power of the government; (2) it furthers an important or substantial governmental interest; (3) the governmental interest is unrelated to the suppression of free expression; and (4) the incidental restriction on alleged First Amendment freedoms is no greater than is essential to the furtherance of that interest. 391 U.S. at 376-377. intended to express an idea.) Rehnquist denied the contention that, while the statute's general prohibition on public nudity may be unrelated to suppressing free expression, by banning nude dancing the state seeks to prevent its erotic message. Specifically, Rehnquist asserted that the state was not proscribing nudity because of the erotic message, but was only "making the message slightly less graphic" by requiring dancers to wear "pasties" and "G-strings" and thereby addressing the evil it sought to prevent-public nudity.

It was not the dancing, with its communicative element, that the state prohibited, but public nudity, whether or not it is combined with expressive activity. Finally, and no doubt with tongue in cheek, Justice Rehnquist found that the public indecency statute was narrowly tailored to achieve its end, since the requirement that dancers wear at least "pasties" and a "G-string" was the "bare minimum" necessary to achieve the state's purpose. See 111 S.Ct. at 2463.

Justices Scalia and Souter concurred in the upholding of the Indiana statute, but they disagreed about why it should be upheld. Justice Scalia viewed the public indecency law as a general law regulating conduct and not specifically directed at expression. Thus, he argued the statute should not be subject to First Amendment scrutiny at all. By contrast, Justice Souter provided a far more cautious fifth vote to uphold the statute. He agreed with both the plurality and dissent that the nude dancing at issue in this case is subject to a degree of First Amendment protection, and agreed with the plurality's use of the O'Brien test. But, he wrote separately because he viewed the justification for the statute to be not public morality- the position taken by both the plurality and Justice Scalia-but the substantial governmental interest in combating the secondary effects of businesses offering nude dancing as entertainment. Souter's analysis under the O'Brien test thus finds support in both the Young and Renton decisions. 111 S.Ct. at 2469-2470.

The four dissenters, in an opinion written by Justice White, argued that the statute serves different purposes when it bans nudity in two settings-adult establishments versus public places such as beaches and parks. In the latter case, the purpose is to protect the public from offense. But in the former case, since the viewers are adults who have willingly paid to be in attendance, the purpose is to protect the viewers from what the state believes is the harmful message that nude dancing communicates. Thus, in White's view, Rehnquist's argument that the state is not "prohibiting nudity because of the erotic message conveyed by the dancers" but only because of the nudity, is "transparently erroneous" because the nudity is itself an expressive component of the dance, not merely incidental "conduct."

Since the statute directly regulates expressive activity, White argues, it may be justified only by a compelling state interest that is narrowly drawn. Indiana impermissibly chose

9. "It is only because nude dancing performances may generate emotions and feelings of eroticism and sensuality among the spectators that the State seeks to regulate such expressive activity, apparently on the assumption that creating or emphasizing such thoughts and ideas in the minds of spectators may lead to increased prostitution and the degradation of women. But generating thoughts, ideas, and emotions is the essence of communication. The nudity element of nude dancing cannot be neatly pigeonholed as mere 'conduct' independent of any expressive component of the dance." Id. at 2474 (footnote omitted). 


\section{Commentary}

to ban an entire category of expressive activity, White asserted, rather than narrowly tailoring a statute to address prostitution and associated evils, or using its authority under the 21st Amendment to regulate nude dancing in bars. ${ }^{10}$

Justice Souter's concurring opinion has strongly influenced subsequent court decisions because he cast the fifth crucial vote to uphold the statute. In Barnes, Rehnquist and Scalia gave a green light to state and local governments to bar nude dancing on public morality grounds; however, Justice Souter's concurring opinion requires such regulations to be aimed at preventing harmful secondary effects of the adult uses. As a result, courts have routinely upheld ordinances prohibiting nude dancing in adult entertainment establishments based on a showing that the ordinance was aimed at avoiding undesirable secondary effects. ${ }^{11}$ The courts, however, have struck down ordinances that extended the nude dancing ban to "mainstream" establishments ${ }^{12}$-or, conversely, upheld exceptions to the ban that are limited to "mainstream" establishments ${ }^{13}$ - because there is no evidence that nude dancing in such establishments produces undesirable secondary effects. Courts also have not hesitated to strike down ordinances (targeting nude dancing) that were motivated by an intent to suppress protected expression rather than to prevent harmful secondary effects. See Triplett Grille, Inc. v. City of Akron, 816 F. Supp. 1249 (N.D. Ohio 1993). Similarly, courts have voided ordinances regulating nude dancing on the basis that the ordinances were unconstitutionally vague or overbroad. See Pel Asso, footnote 12.

\section{LICENSING ORDINANCES}

In FW/PBS, Inc. v. City of Dallas, 493 U.S. 215 (1990), six Justices of the Supreme Court found that the licensing provisions of a comprehensive adult business ordinance raised significant First Amendment problems because the licensing requirement imposed a prior restraint on freedom of expression. A prior restraint was found because, rather than penalizing expression after it occurred, the licensing scheme prevented the expression from occurring in the first place. While such prior restraints are not unconstitutional per se, there is a strong presumption that they are not constitutionally valid. The six Justices split evenly, however, on what procedural safeguards were required to validate an adult use licensing ordinance.

All Justices agreed that such ordinances must not "place unbridled discretion in the hands of a government official or agency"; must require a definite time limit within which the decision maker must issue or deny the license, during which time the status quo must be maintained; and must allow for

10. See Newport v. Iacobucci, 479 U.S. 92 (1986) (per curiam); New York State Liquor Auth. v. Bellanca, 452 U.S. 714 (1981) (per curiam); California v. LaRue, 409 U.S. 109 (1972).

11. See, e.g., Bright Lights, Inc. v. City of Newport, 830 F. Supp. 378 (E.D. Ky. 1993); Dodger's Bar \& Grill v. Johnson County Bd. of Comm'rs, 815 F. Supp. 399 (D. Kansas 1993); O'Malley v. City of Syracuse, 813 F. Supp. 133 (N.D. N.Y. 1993); Gravely v. Bacon, 263 Ga. 203, 429 S.E.2d 663 (1993); S.J.T., Inc. v. Richmond County, 263 Ga. 267, 430 S.E. 2 d 726 (1993).

12. See, e.g., Pel Asso, Inc. v. Joseph, 262 Ga. 904, 427 S.E.2d 264 (1993).

13. See, e.g., Top Shelf, Inc. v. Mayor and Aldermen for City of Savannah, 840 F. Supp. 903 (S.D. Ga. 1993); S.J.T., supra note 11, at n.17. prompt judicial review if the license is erroneously denied. But in addition, Justices Brennan, Marshall, and Blackmun argued that a licensing ordinance must require that the government bear both the burden of going to court to enforce the denial of a license application and the burden of proof in court. Justice $\mathrm{O}^{\prime}$ Connor wrote an opinion arguing for the lesser standard, which was joined by Justices Kennedy and Stevens. Justice Brennan's opinion calling for the stricter standard was joined by Justices Marshall and Blackmun. ${ }^{14}$

Recent decisions applying the FW/PBS ruling have struck down licensing ordinances that lacked effective time limitations (see Chesapeake B $\mathcal{E} M$, Inc. v. Harford County, $831 \mathrm{~F}$. Supp. 1241 (D.Md. 1993), 46 ZD 111), or failed to limit the discretion of city officials to grant or deny a license. See Wolff v. City of Monticello, 803 F. Supp. 1568 (D.Minn. 1992), 45 ZD 257 . On the other hand, courts have upheld ordinances with the appropriate safeguards. See 11126 Baltimore Blvd., Inc. $v$. Prince George's County, 828 F. Supp. 370 (D.Md. 1993), 46 ZD 112.

Courts have also struck down licensing ordinances that charged higher fees for adult businesses, because this regulated on the basis of the content of expression (see AAK, Inc. $v$. City of Woonsocket, 830 F. Supp. 99 (D.R.I. 1993)) or required licensing of shareholders in an adult business, because this did not advance any substantial governmental interest unrelated to suppression of speech. See T.K.'s Video, Inc. v. Denton County, 830 F. Supp. 335 (E.D. Tex. 1993).

Also, courts have applied the FW/PBS standard to strike down conditional use requirements that raise concerns about a prior restraint identical to those raised by a licensing ordinance, requirements that vested overbroad discretion in a city official-see 11126 Baltimore Blvd. v. Prince George's County, 684 F.2d 884 (D. Md. 1988) and J.L. Thomas, Inc. v. County of Los Angeles, 283 Cal. Rptr. 815 (2d Dist. 1991)-or did not provide for specific time limits for decision making. See Thomas, supra, and People v. Library One, Inc., $280 \mathrm{Cal}$. Rptr. 400 (2d Dist. 1991).

\section{PUBLIC HEALTH REGULATIONS}

Recently, numerous courts have addressed the regulation of adult businesses via public health regulations rather than zoning. Often these courts assess the constitutionality of regulations that require adult businesses to make viewing booth interiors open to public view by removing the booth doors. ${ }^{15}$ These "open door" requirements designed to decrease illicit sexual activity and/or the spread of AIDS, ${ }^{16}$

14. The procedural safeguards about which the Justices disagreed were first stated in Freedman v. Maryland, 380 U.S. 51 (1965).

15. See Mitchell v. Commission on Adult Entertainment Establishments, 10 F.3d 123 (3d Cir. 1993); Doe v. City of Minneapolis, 898 F.2d 612 (8th Cir. 1990); Berg v. Health and Hospital Corp. of Marion County, 865 F.2d 797 (7th Cir. 1989), 41 ZD 325; Bamon Corp. v. City of Dayton, 730 F. Supp. 80 (S.D. Ohio 1990), 42 ZD 348; Postscript Enters. v. City of Bridgeton, 699 F. Supp. 1393 (E.D. Mo. 1988); Suburban Video v. City of Delafield, 694 F. Supp. 585 (E.D. Wis. 1988), 41 ZD 165; Adult Entertainment Center v. Pierce County, 57 Wash. App. 435, 788 P.2d 1102 (Wash. App. 1990).

16. Many of the cases cited in the preceding footnote document the extent to which viewing booths with closed doors may be used for illicit sexual activities by facilitating sexual activity either between two persons occupying a single booth or by persons in adjoining booths by means of a hole in a common wall. 


\section{Commentary}

have been upheld as valid "time, place, and manner" restrictions on expression ${ }^{17}$ that do not implicate patrons' privacy rights. ${ }^{18}$

However, such ordinances may still be invalid, in part, if they violate other constitutional safeguards. For example, in Suburban Video v. City of Delafield, 694 F. Supp. 585 (E.D. Wis. 1988), the court invalidated those portions of the ordinance's adult business licensing scheme that required applicants to supply large amounts of personal information that had no relationship to the ordinance's stated purpose of fighting the spread of AIDS. In effect, the courts found that these provisions were an unjustified prior restraint on expression and violated owners' and employees' right to privacy.

\section{CONCLUSION}

These recent court decisions provide local officials with clear guidelines to follow when enacting adult businesses regulations. First, and most critically, officials must recognize that the only permissible goal of adult business regulation is the reduction of their undesirable secondary effects, and that courts will not hesitate to invalidate zoning re-

\section{See Mitchell, Berg, and Adult Entertainment Center, footnote 15.}

18. See Berg, Adult Entertainment, Bamon, and Suburban Video, footnote 15. In these cases the courts rejected arguments that patrons have a constitutional right to view adult films (Berg) or engage in sexual activity, including masturbation (Adult Entertainment), behind closed doors in a public establishment. strictions and other forms of regulation-including restrictions on nude erotic dancing-when they are merely a pretext for eliminating or unduly restricting adult businesses.

Second, because courts are scrutinizing the secondary effects justification for adult business regulation more closely, local officials must exercise caution if they choose to rely on the findings of other communities, rather than documenting the negative impacts of secondary effects in their own community. Courts are now requiring officials to demonstrate that they gave a reasonable degree of consideration to such findings prior to enacting their own restrictions. Judges are also reexamining to what degree any given local adult business may differ from the businesses in the community whose documented secondary effects were used by local officials to justify their own regulations.

Third, since local officials must expect that their locational restrictions will be reviewed under the "relevant real estate market" standard, they should ensure that their regulations leave adult businesses with an adequate number of sites that are either zoned for commercial development or, if zoned otherwise, are generally suitable for some form of commercial enterprise. Finally, courts will give local officials significant leeway, but not total latitude, when enacting regulations to address the public health concern raised by adult businesses, such as restrictions that seek to prevent patrons from engaging in sexual activity on the premises. 